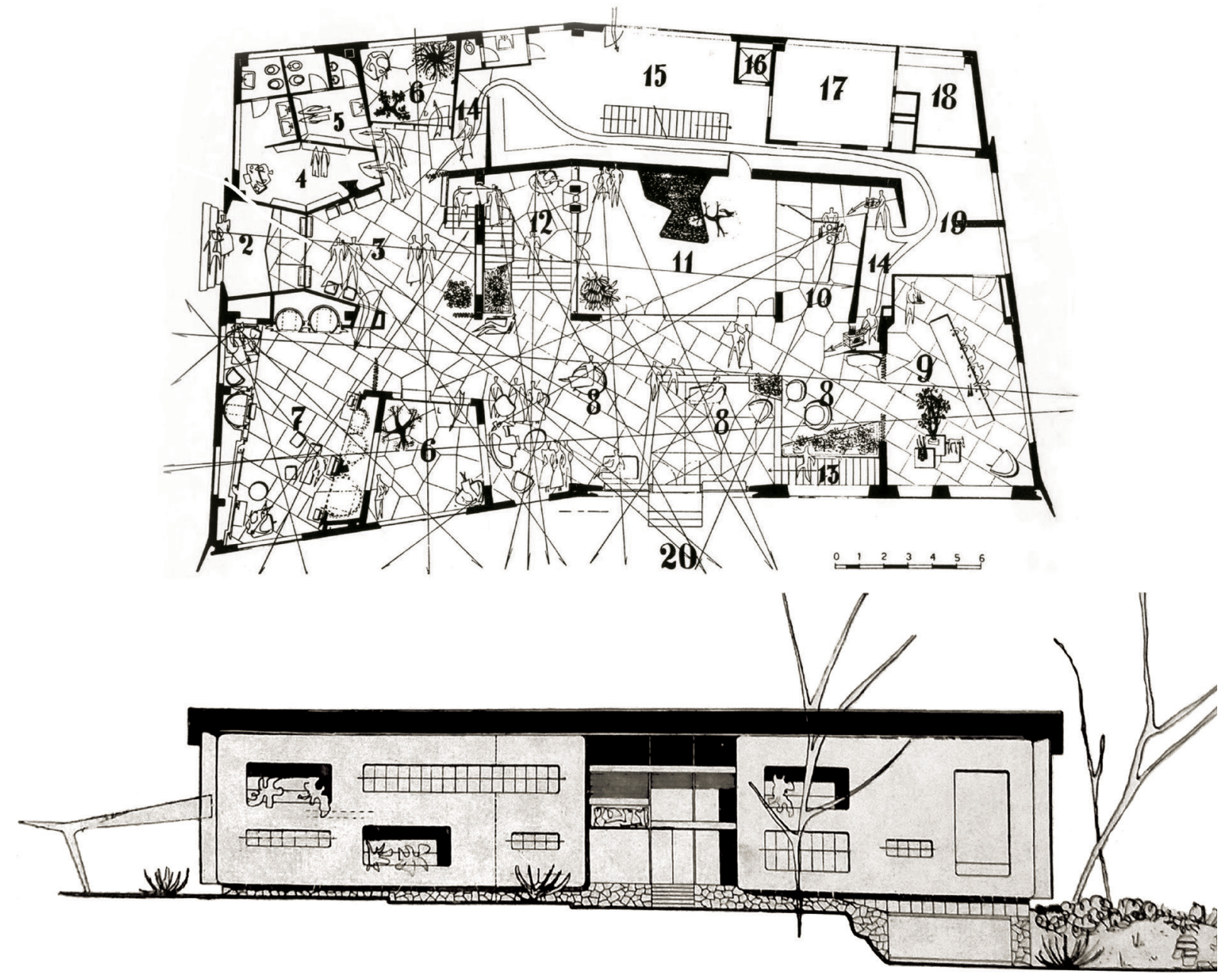




\section{Who Designed Villa Planchart? Gio Ponti's Architecture in Caracas: Between Influences and Contamination Giorgio Danesi}

In 1953, Armando and Anala Planchart asked the Italian architect Gio Ponti to realize a new house for them in Caracas. They did not know at the time that it would become one of the most iconic works of twentieth century architecture: "Can I be your Michelangelo?"1 Nevertheless, the correspondence between the architect and several of the individuals involved in its construction testifies to the multiple influences that can be recognized in the house. This makes it one of the clearest examples of building with the involvement of multiple authors.

KEYWORDS

Villa Planchart, Caracas, Gio Ponti, Collective Authorship, Clients

PALABRAS CLAVE

Villa Planchart, Caracas, Gio Ponti, autoría colectiva, clientes

Designed in Milan by Gio Ponti and built in Caracas by Mario De Giovanni and Graziano Gasparini between 1955 and 1957, Villa Planchart came into being through a "long distance dialogue" between enlightened protagonists: the clients and construction technicians in Venezuela and the architect and the providers of high-quality materials and furnishings in Italy.

In June 1953, Armando and Anala Planchart asked the editor of Domus to be involved in the project of designing their new house: an "ambitious Venezuelan wager," ${ }^{\prime 2}$ that gave rise to an iconic twentieth-century work of architecture, a clear embodiment of Gio Ponti's style. A "utopian project"

\author{
Giorgio Danesi \\ graduated with honors in Architecture \\ for Conservation (Master Degree) from \\ the Università luav di Venezia in 2013. \\ Since 2018, he received a PhD in the \\ History and Conservation of Architecture, \\ with a thesis focused on the twentieth- \\ century restoration work on St. Mark's \\ Basilica (Venice). In 2020, he was post- \\ doctoral fellow in the research project: \\ "Correspondences: Villa Planchart from \\ Design to Materiality," which was dedicated \\ to the documentation and conservation \\ of the well-known architecture by Gio \\ Ponti in Venezuela. Since 2020, he has \\ been an adjunct professor of Architectural \\ Preservation at the University of Udine. \\ His main research interests focus on the \\ conservation of twentieth-century heritage. \\ E-Mail: giorgioisedanesi@gmail.com \\ ORCID iD: 0000-0001-7189-1865
}

Fig. 01

Villa Planchart, Caracas. Ground floor plan designed by Gio Ponti in 1954 (Domus, 1961); and north façade draft (Domus, 1955). 
Fig. $\mathrm{O} 2$

Villa Planchart, Caracas. The concrete roof over the east façade entrance, 2020 (photo: ISC Technology, Docomomo Venezuela).

Fig. 03

Villa Planchart, Caracas. North façade view and details, 2020 (photo: ISC Technology, Docomomo Venezuela). established to create a "complete work of art"3 was designed and built based on letters, sketches, drawings, and brief visits to the building site on the other side of the Atlantic. This project represented a geographical and intellectual challenge. The result combined the ideas of cultured clients with the personal style of the architect, who realized the building from a great distance.

The outcome of this process is regarded as a "four-handed score" assisted by "an orchestra of artists and craftsmen from the two continents," which has been preserved in the wealth of correspondence exchanged by the protagonists. ${ }^{5}$ These letters overcame the physical distance between the two countries and made it possible to translate the new idea of architecture, art, and living that we can recognize in the house into reality.

At the same time, the original design for the building was modified in the construction phase. In Villa Planchart, several factors transformed the initial idea into a "local translation": the availability of materials, the contingencies of the building site, and the skills of the craftsmen. Many details of the built architecture do not correspond to the executive drafts developed in Milan: "The individuals who conceived the design were not able to see the building develop. At the same time, the individuals who saw it develop did not see it being designed."

Starting from the analysis of the archival documents, the study aims to increase our knowledge of how this building was created, ${ }^{7}$ and to critically verify the multiple origins of the project design that resulted from the influence of the clients and the contributions of the technicians. The objective is to extend the concept of authorship for a work of architecture that should not only be regarded as a "masterpiece"8 with the sole involvement of Gio Ponti (fig. 01).

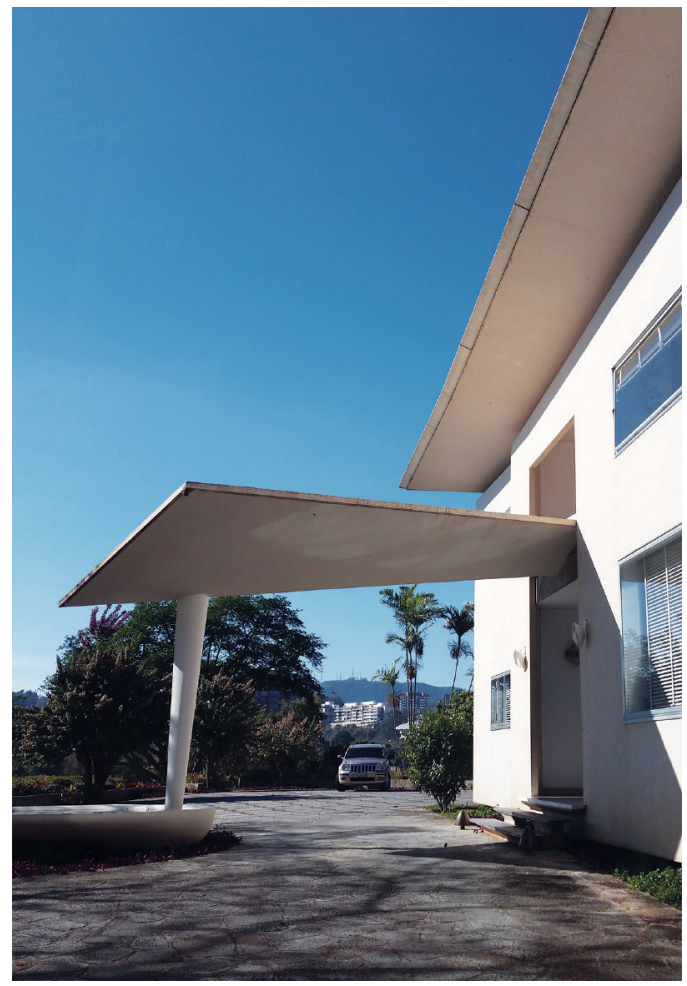




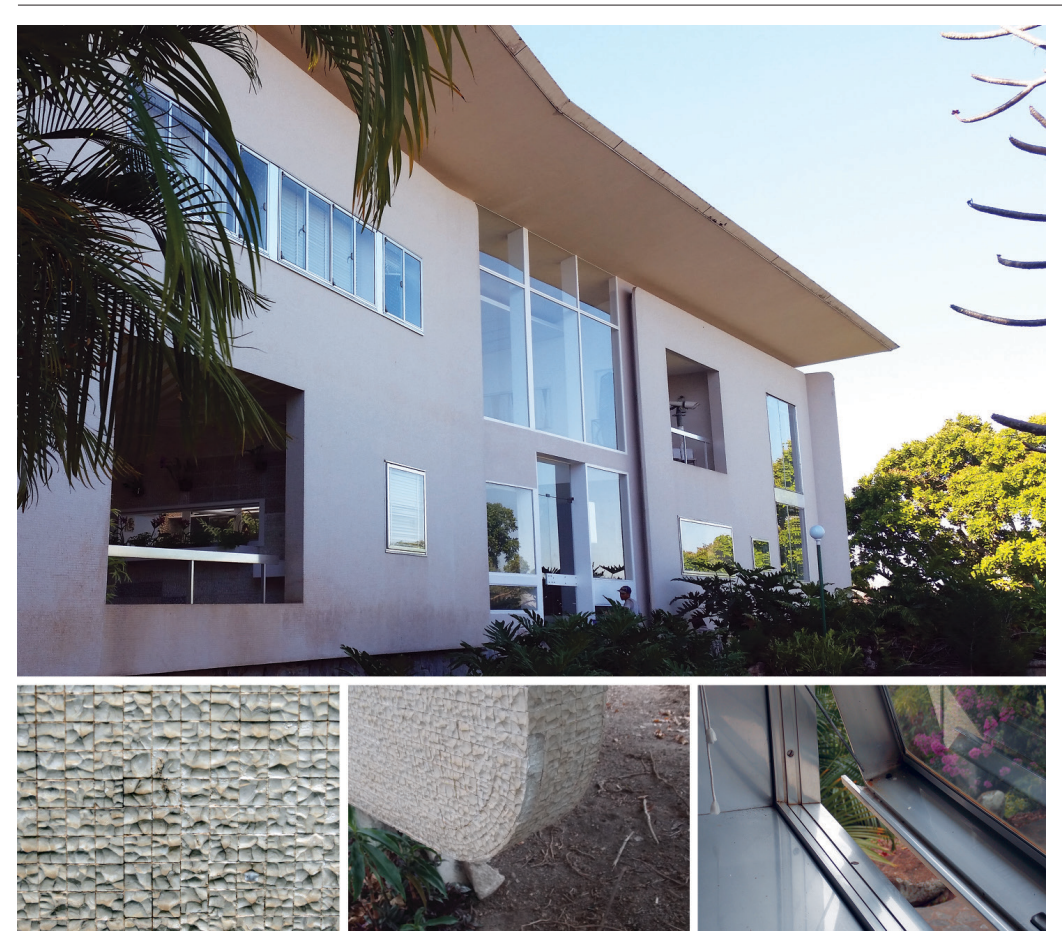

$\mathrm{O3}$

GIO PONTIIN CARACAS
Villa Planchart is a huge mansion located on the top of San Roman Hill ${ }^{9}$ in Caracas with a panoramic view over the city (fig. 02). It is a compact white building surrounded by a luxurious tropical garden. Gio Ponti studied multiple approaches to giving this modern building an impression of

lightness: "I have dreamed of a house that leans gently on the ground like a white butterfly." consisting of surfaces that are visually distinct from one another. $\mathrm{He}$ achieved this result by using a specific reinforced-concrete construction system based on cantilever beams. The perimeter walls seem to be physically disconnected from the ground and the wide roof overhang. $A$ system of neon illuminates the surfaces of the villa at night, thus augmenting the idea of visual lightness.

The external walls are characterized by different kinds of white ceramic mosaics and modern steel windows, while the interiors display a plethora of high-quality materials: marble, bronze, various types of wood, decorated plasterwork, and handcrafted tiles (fig. 03). Everything in Villa Planchart was designed in detail specifically for the house: the furniture, works of art, and even the crockery.

This approach to design characterized Gio Ponti's works particularly in the 1950s. We can find the same approach in his other works of the same period. The two most meaningful examples are Villa Diamantina, built in Caracas for Mr. and Mrs. Arreaza, ${ }^{11}$ and Villa Nemazee, built in Teheran for Vida and Shafi Nemazee. ${ }^{12}$ There are similarities between the three houses, testifying to the many analogous ideas that the architect proposed to his various clients. For example, we recognize similar solutions for the layout of the rooms and the visual 
Fig. 04

Villa Planchart, Caracas. The wooden furniture realized by Giordano Chiesa, including the rotating shelving for hunting trophies, 2020 (photo: ISC Technology, Docomomo Venezuela). connections between them; the use of extensive, structured glass walls; the repeated use of particular colors (blue for Diamantina and Nemazee, yellow for Planchart); the geometrical decoration of ceilings, as if they were multicolored carpets; the use of mosaics as external claddings; and the introduction of unique "movable furniture." In the Villa Planchart, for example, the rotating shelving of hunting trophies (in the library/studio) seems to be the result of a negotiation between the client and architect. Ponti did not appreciate his client's original idea of presenting trophies on the wall without the possibility for them to be hidden (fig. 04).

The construction of Villa Planchart coincided with a period of intense work in Gio Ponti's firm. In the 1950s, his professional activity increased in conjunction with Italy's economic growth. In those years, he was involved in prestigious projects, such as the Pirelli skyscraper in Milan, ${ }^{13}$ where he experimented with the "diamond-shaped" architectural volumes that we also see in Villa Planchart.

As Ponti said, ${ }^{14}$ the general design of the house came from the technical and architectural solutions that he experimented with in the design for the Institute of Nuclear Physics in San Paolo ${ }^{15}$ and the "Fondazione Lerici" Italian Institute of Culture in Stockholm, ${ }^{16}$ as well as in the

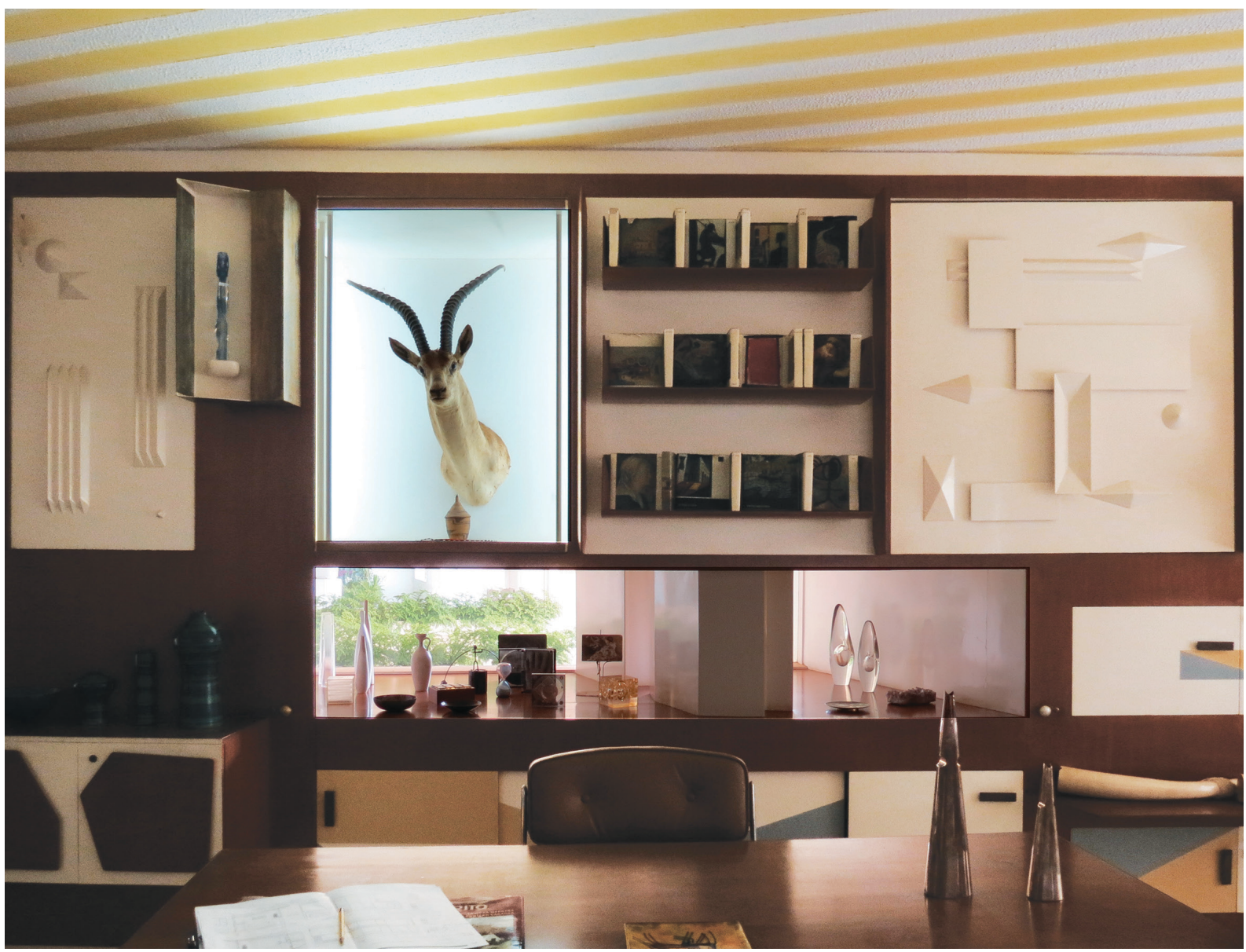


"Fondazione Aldo Garzanti" in Forli." In these buildings, we can clearly recognize the use of separate surfaces for the perimeter and huge wing-shaped roofs, which unmistakably call to mind the exterior of Villa Planchart. ${ }^{18}$

ARMANDO

AND ANALA PANCHART: THE CLIENTS' ROLE
A particular aspect of Villa Planchart's "construction story" lies in the conspicuous contribution that the clients made to defining the project design. They influenced the genesis of the idea, as well as the executive drafts. Their contribution extended into the construction phase, thus establishing a respectful and proactive dialogue with Ponti: "The request has always been intelligent, clear, discreet, made with confiding friendship by the incomparable people to whom I have dedicated this work."19 Thanks to such "liberal and receptive" ${ }^{20}$ customers, Gio Ponti had the opportunity to begin and complete "the happiest intuition of his older age."21

The extensive correspondence exchanged between 1953 and 1957 helps us understand the intellectual affinity and the strong bond that develops between architect and clients. As Letizia Fralich-Ponti -Gio Ponti's daughter, who translated her father's correspondence- reminds us: "The letters they wrote reflect these special characters and their harmony."22 The architect made his appreciation for the couple public on several occasions: "In architecture we talk about many things, but rarely do we talk about the 'good client,' to whom goes all the credit if the building can be realized. ${ }^{\prime 23}$ In Domus, ${ }^{24}$ Ponti repeatedly declared that the work had been possible thanks to these "perfect customers." By default, this project was difficult to complete owing to the enormous physical distance between the site and designer: "Vitruvius says that in architecture the client is the father, while the architect is the mother. The clients in Caracas have been exemplary parents. Not only due to the large amount of funding they decided to dedicate to their house, but also for the human sympathy, the rare discretion, the understanding and the trust with which they accompanied the work of the architect, by multiplying his enthusiasm."25

Villa Planchart's story involved an ongoing "search for beauty," which united the clients and architect, and the Plancharts contributed to this process with "intelligent and lively"26 participation. For a short period, Armando Planchart replaced the building's site manager, taking several photographs to update the architect himself about the progress of the work. Planchart's wife, Anala neé Braun Kerdel, also played a decisive role, especially in defining the garden design -an opportunity to express her passion for botany- but also in choosing the works of art for the house, and expressing her ideas about the interiors: "I want a house without walls."27

The Plancharts were part of Venezuela's wealthy and cultural elite, and Gio Ponti belonged to the same social class in Italy, which allowed them to connect as peers. Among their common interests were not only a propensity for modern architecture, but also an intense passion for design and art, and, more generally, an ongoing commitment to cultural events. Thanks to Domus, they learnt to appreciate the modern vision of the Italian architect and his ability to combine architecture and art in a single approach to designing. The decision to entrust the design of their home to the well-known editor of Domus magazine arose from this premise. Despite his initial refusal, ${ }^{28}$ Ponti accepted the assignment in 1953, starting an ongoing and intense relationship with the couple. $\mathrm{He}$ 
Fig. 05

The interior garden walls with potted tropical plants in Villa Planchart and various details 2020 (photo: ISC Technology, Docomomo Venezuela).

Fig. 06

Villa Planchart, Caracas. Night view, 1957 (GPA Archive website).
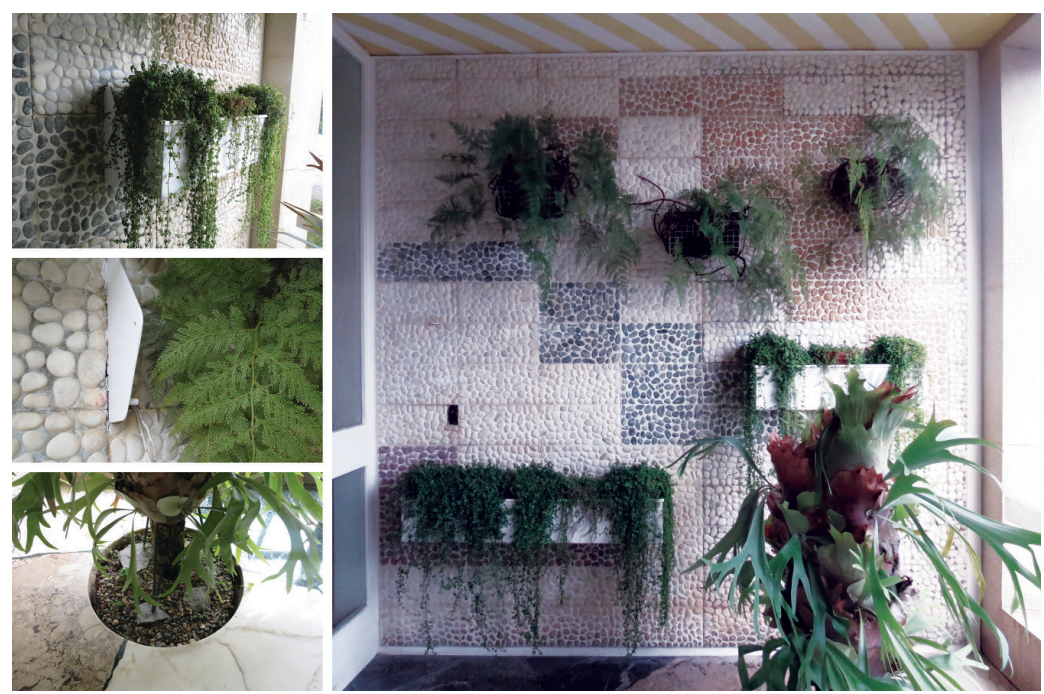

05

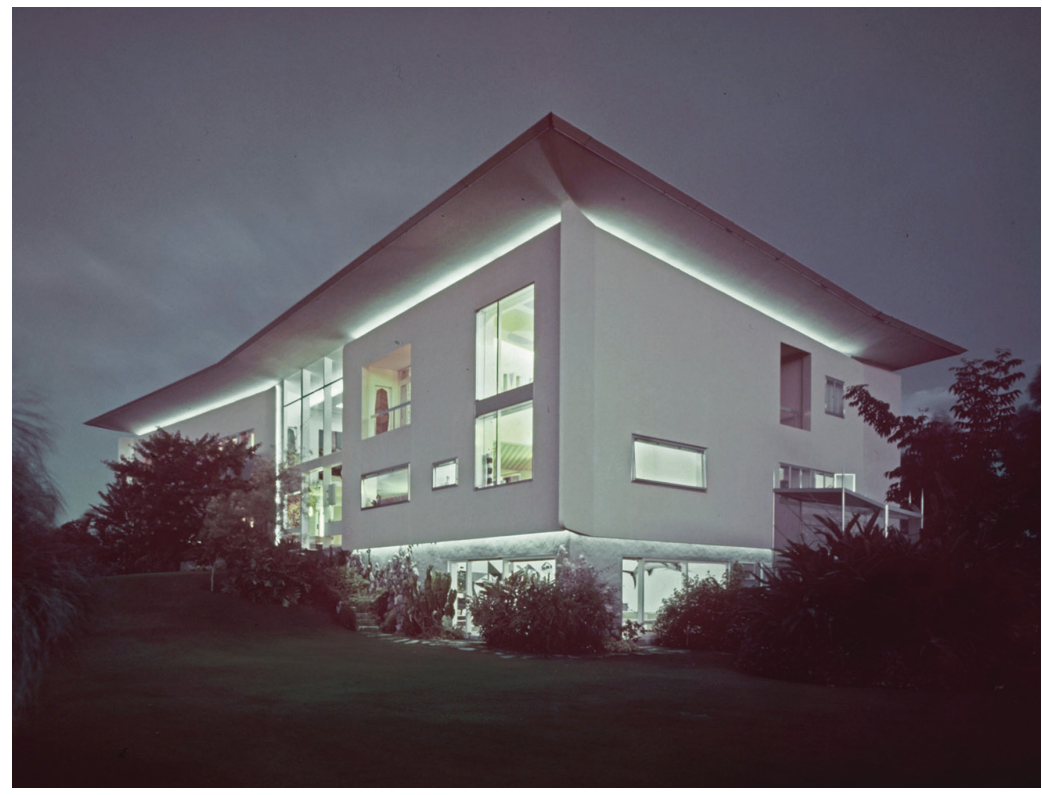

06

first proposed a sketch of a "colonial villa," but the Plancharts immediately shared their desire for a "modern house," stimulating the interest of their interlocutor. During this preliminary stage, an exchange of letters was the main means through which they were able to share their passions and habits. They could ask for advice and address the architect on the primary needs related to their way of living: "We represent a simple marriage, without children ...., our friendships are not just representative relationships; we also like to meet them frequently. Our passions are plants, dogs, birds, fish, photography, et cetera." ${ }^{29}$

Ponti declared that he gave "all his time to architecture, instead of fighting with self-injurious clients." 30 The Plancharts were eager to listen to the solutions he proposed but, as is evident several 
times in the correspondence, they never failed to express their opinion about every single choice: "I want the house to be completely to your taste, but also to ours." 31

In 1953, when they got in touch with Ponti, they had very clear ideas about the kind of house they wanted. Armando, at the peak of his career, ${ }^{32}$ was forty-six years old and Anala forty-two. The couple, married since $1935,{ }^{33}$ had already lived in various houses. These places became the starting point for elaborating their own idea of a "perfect home." Villa Planchart was going to become "the home of their life."34 As Anala Planchart testified in a series of interviews with Hannia Gomez, ${ }^{35}$ four houses characterized their everyday life prior to the ambitious project of creating a modern building on the top of San Roman Hill.

The first reference is the place where Anala spent her youth, the "Braun-Kerdel house," a traditional Venezuelan house in the center of Caracas, filled with "beautiful objects, works of art, plants, and flowers," ${ }^{36}$ built around a patio that was central to the daily rhythm of her life. The centrality of the patio in the distribution of the rooms was thus one of the first themes to which Gio Ponti directed his attention. Among the challenges in designing the building was the ongoing attempt to combine the principles of modern architecture with the desire to incorporate the indoor gardens and tropical plants typical of traditional Venezuelan architecture, and necessary so as to do justice to Lady Anala's perceptive memories (fig. 05).

After 1935, the couple spent a few years in her grandparents' property, an eclectic house called "Mi Rancho," located in the district of EI Paraiso and built at the end of the nineteenth century by a French garden designer. ${ }^{37}$ The entrance to the house via a staircase preceded by a huge mango plant remained in Anala Planchart's memory for years. For this reason, in front of Villa Planchart, she planted the majestic Samàn tree that we can still appreciate in the background of Ponti's concrete roof.

The Planchart's experiences of home were not limited to the traditional houses of high-ranking citizens of Caracas and the French colonial experiments of the late nineteenth century. The avantgarde spirit of the couple led them to research the principles of modern architecture for over a decade before meeting Gio Ponti. In the 1940s Mr. Planchart obtained a plot of land in the Upper Florida district of Caracas and built a modern house -called "Guari"- where the couple lived for over ten years. The project was designed entirely by Lady Anala, without the assistance of any architect..$^{38}$ It represented that International Style that they became familiar with and learned about in-depth through browsing architecture magazines. The characteristic white surfaces, the oculus windows, and the cantilevered cornices were combined with the illumination of the building profiles. This immediately reminds us of the image of Villa Planchart by night that is preserved in the Gio Ponti Archive in Milan, even though "Guari" anticipated it by more than a decade (fig. 06). In this house, filled with artworks, there are only partial similarities with the imposing future home, Villa Planchart. The dimensions were smaller and the surfaces were not covered with the ceramic mosaics that characterize the building designed by Ponti: "It was very simple, on one floor, without tiles." ${ }^{\prime 9}$ Past life experiences also became occasions to clarify some uncomfortable aspects that were not to be repeated: "... the house was very poorly oriented, because it was too sunny in the afternoon."40 This 
experience convinced Armando and Anala to request a correct orientation for the new house in the preliminary design phase: "... the sun has to enter as little as possible from the west side."41

The final influence that we can identify in the past life of the Planchart family comes from their holiday home: "Casa de la playa," also called "Churuata." It was a seafront house, situated on the coast beyond the mountain range facing Caracas. It was built in 1945 by Pedro Agustin Dupouy, the same engineer who realized the "Cars" building, the headquarters of Mr Planchart's car dealership. ${ }^{42}$ The house, with a fully "modern shape," consisted of two perpendicular white prisms with a reinforced concrete structure characterized by ribbon windows and a flat roof. Three steps divided the interior from the garden and lifted the building off the ground visually, giving it that respectful distance between its perimeter walls and the ground floor that we also find in Villa Planchart (fig. 07). The interiors, rich in tropical vegetation, showed colors and shapes similar to the majestic house on San Roman Hill that the owners would shortly thereafter ask Gio Ponti to design, bringing together the memories of all the houses the Plancharts had lived in until that point in time, and creating "a perfect set, designed for the people who had to live there day after day. ${ }^{1,3}$

The houses inhabited by Armando and Anala represent one of the influences on Villa Planchart, and clearly show the couple's interests: they were "discreet clients," ${ }^{\prime 4}$ but aware of what they wanted for their home.

Ponti always took the Plancharts' repeated demands for modifications into consideration, also during the construction phase. He often pointed out that every choice had to align with the project as a whole: "You have to know that I am always happy when I can please you, without making mistakes in the overall design project." ${ }^{\text {"45 }}$ The Plancharts thus convinced Ponti to modify the project many times and in many different aspects. They asked for a reduction of the overall dimensions; the addition of an elevator with little glass windows on the sliding doors; the replacement of the garage in the basement in the original design with a game room; and the addition of a concrete roof over the entrance to shield vehicles. They also convinced the architect to pave most of the first floor with a Venezuelan wood parquet, even if wood was not one of the materials that Ponti encouraged using based on his idea of "modern architecture." The correspondence reveals that Plancharts influenced the distribution of the bathrooms, bedrooms, and kitchen, and introduced many details that characterize the house. Revealing his technical skills, Armando Planchart worked with technicians in Venezuela to improve various aspects of the electrical system as well as the waterproofing of the walls. ${ }^{46}$

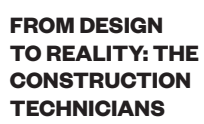

When the project moved from the preliminary design phase to the execution phase, a pressing need for a local figure to clarify numerous technical issues arose. The construction site was too far away to be managed solely by Ponti from Milan: "I will be happy to have at my service an architect from Venezuela who is your friend and who can collaborate to re-read the drafts that I dedicate to you with all my passion."47

The couple's various leisure trips ${ }^{48}$ required the stable presence in Caracas of reliable figures who could communicate long distance with the architecture firm in Italy during their absences. Moreover, Ponti was aware that he would encounter numerous bureaucratic obstacles by working 

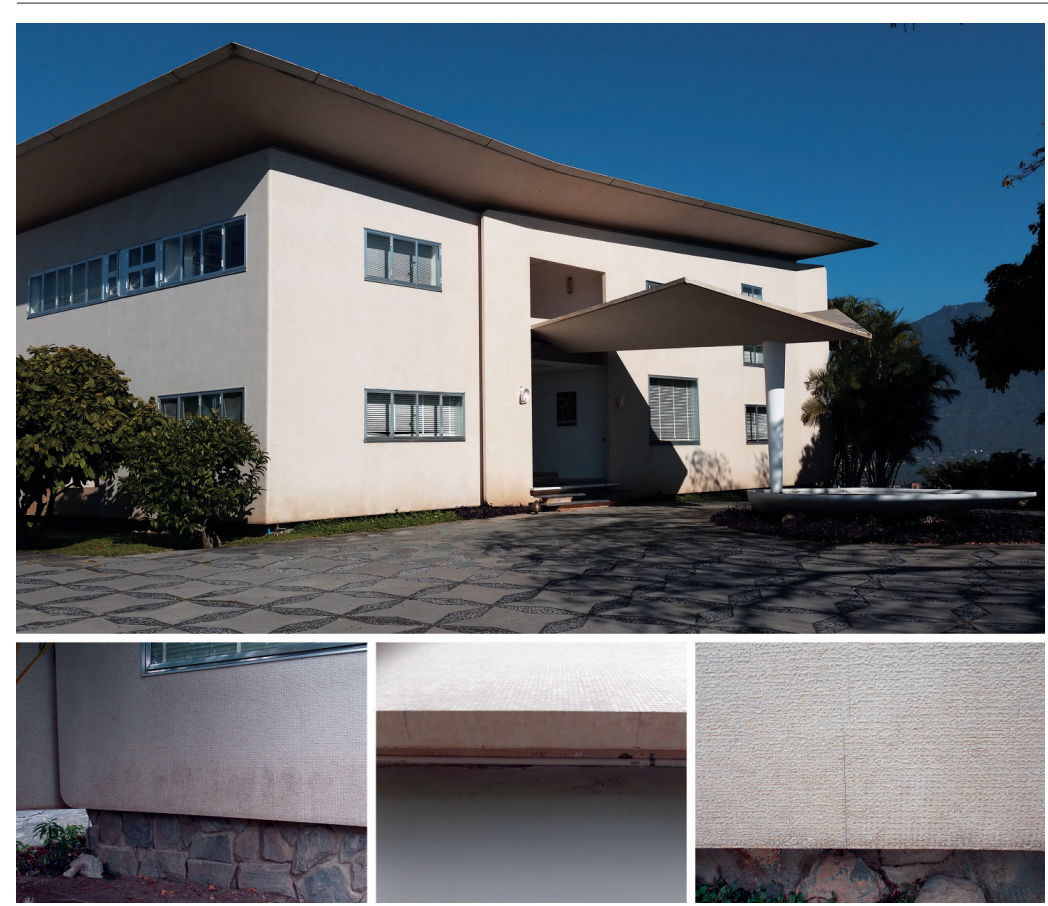

07

in a foreign country. A local technician could deal with many difficult situations: "How can I guarantee the best project, and do an exceptional job while complying with the regulations in Caracas, with which I am not familiar?"49

Mario De Giovanni was the first professional brought in by the owners. The choice fell on the engineer ${ }^{50}$ because of his Italian origins, which would be helpful in communicating with Ponti's firm, but also because of his great friendship with the clients' family. In addition, he had already worked on their parcel of land, preparing the ground and creating the first access paths to the top of the hill. ${ }^{51} \mathrm{He}$ knew not only the area very well, but also the characteristics of the tropical climate and the city's building regulations: "About the idea of removing the insulation from the project of the walls, I trust you, because you know the climate characteristics." ${ }^{32}$ De Giovanni was the owner of the Caracas-based construction company "MADE." For the Plancharts' project he was in charge of monitoring the plans drawn up in Milan; providing the design for the hydraulic system; clarifying the structural design in cooperation with Ponti's firm; and supervising construction on the building site.

During the three years of collaboration, Ponti several times expressed great esteem for his Venezuelan colleague, who was very precise: "Praise to you, who made the walls with the precision of a furniture maker."53 He contributed not only to the execution, but also to the incorporation of significant improvements to the project. His brilliant solutions were sometimes necessary to correct mistakes made by Ponti: "All the providential observations that De Giovanni made derived from my errors. His help was providential. ${ }^{, 54} \mathrm{He}$ changed the structural details of many of the reinforced concrete beams, which were impossible to realize structurally as designed in Milan. ${ }^{55}$ $\mathrm{He}$ also modified the slab thickness to comply with local regulations $\mathrm{s}^{56}$ and altered the dimensions of the hollow bricks that had been planned in Milan and replaced them with other bricks available in Venezuela.

Fig. 07

Villa Planchart, Caracas. East façade view and details of the perimeter walls, 2020 (photo: ISC Technology, Docomomo Venezuela). 
Fig. 08

Villa Planchart, Caracas. The decorated metal surfaces realized by the sculptor Romano Rui for the patio fireplace and details, 2020 (photo: ISC Technology, Docomomo Venezuela).

Fig. 09

Villa Planchart, Caracas. The ceramic decorations by Fausto Melotti on the patio, 1961 (Domus, 1961), and details, 2020 (photo: ISC Technology, Docomomo Venezuela).
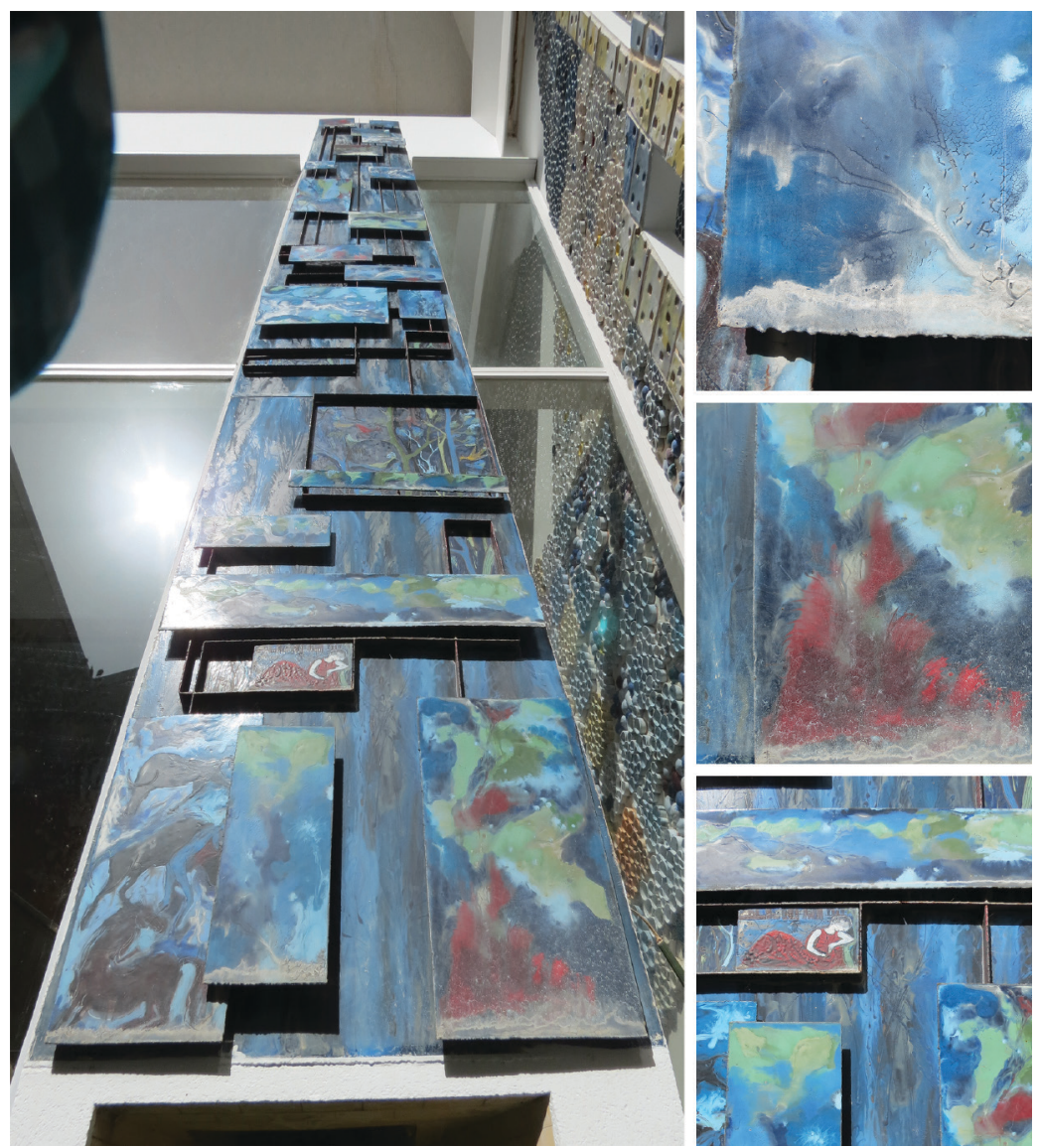

08
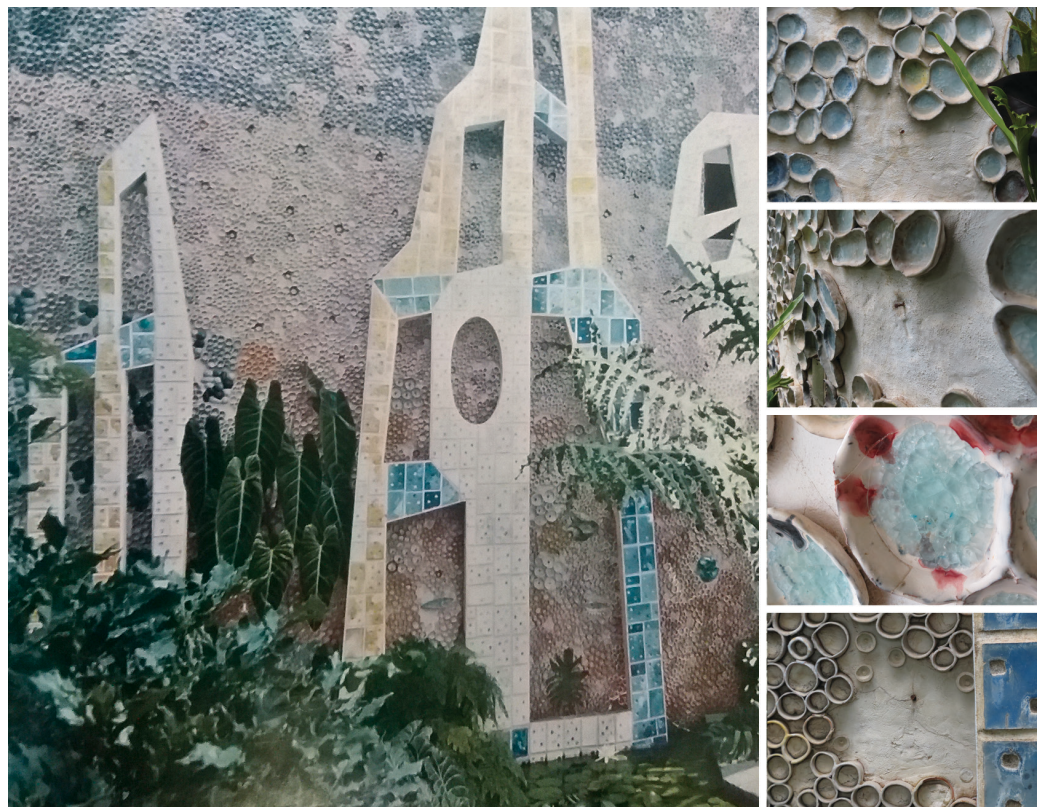

09 
Even though he was quite slow in responding to letters, the Italian-Venezuelan technician proved to be an extremely decisive "collaborator from a distance": "I am glad that you are so precise and tell me everything, because this is a great help to me."57 In March 1954, when Mr. Planchart asked him to alter the overall dimensions of the house, De Giovanni informed Ponti that he had followed the instructions of the clients, changing as few characteristics as possible: "As you will notice, in the reduction of the dimensions, I adhered to your design as faithfully as possible." ${ }^{58}$

Ponti was sometimes forced to accept the changes proposed by his colleague when there was no way for him to assert himself against them. This happened, for example, a few days before the construction of foundation, when De Giovanni communicated that he had to move the position of the building in the garden by a few meters after finding some errors in surveys: "The architect Ponti took note of this and wrote me that he can only rely on your intelligence to consider this change to be the best solution possible." ${ }^{59}$

The engineer's skills were considered essential in the constructive transposition of the structural details designed in Milan, while, in contrast, his design abilities in defining architectural aspects were often questioned by Ponti, as he confided to Armando Planchart: "He has excellent qualities, but he's a bit extravagant, and that's why you have to be very careful about his desire to propose variations." ${ }^{.60}$ Among these ideas were the curious proposal to cover part of the east façade -under the entrance roof- with a "rainbow mosaic"61 and the proposal to paint the end of the perimeter gutter in a dark color: "Please, paint it in white immediately. It looks really bad." 62

Except for the limited compatibility with respect to various formal choices, the collaboration between the two figures continued with confidence into the second year of construction. However, as of 1957, health problems forced De Giovanni to take his leave from the project. The young architect Graziano Gasparini replaced him for the last eight months prior to the inauguration of the house (December 1957), thus bringing a new character into the complex story of Villa Planchart.

Ponti immediately approved of the new site manager. $\mathrm{He}$ recognized the young architect's clearly superior design skills in comparison with his predecessor, which were significant enough for Ponti to make reference to Gasparini in six articles in Domus. ${ }^{63}$ Most of his support focused on completing the decorations defined by Ponti and De Giovanni in the previous years, but he also made his own contributions by suggesting various important details. These included the idea to remove the bird cage from the patio, because, "it is extremely tall and conceals the wonderful decoration of the wall." ${ }^{44} \mathrm{He}$ also indirectly influenced the construction of the external paving of cobblestone and concrete: "I want it to be like the one that Graziano realized for other houses in Caracas."65

He also directed the installation of the works by the three important Italian artists involved in the project: Giordano Chiesa, who realized the unique wooden furniture for the library in Italy, which was then transported by ship to Venezuela; the sculptor Romano Rui, who realized the decorated metal surface for the patio fireplace (fig. 08); and the artist Fausto Melotti, who decorated the patio and the Comedor Tropical walls with vitrified ceramics (fig. 09). 
Thanks to the correspondence, we can understand that the work of these artists was directed by both Gasparini and Ponti, who often gave them the initial input about the artistic project, but gave the artists the freedom to express their own art in the details: "I am studying the decoration of the patio back walls with an extraordinary ceramist. It will be wonderful!... These ceramics are not mine and the author has all the credit for their beauty."66 All the artistic decorations of the house are the result of the cultured collaboration between the Italian architect, the Venezuelan technicians, and the personal contribution of the artists, who definitively took on a part of their own in the authorship of the final work.

CONCLUSIONS

One of the most relevant outcomes of the research is the identification of Villa Planchart as a complex work of art, in which the concept of authorship cannot be linked solely to the well-known figure of Gio Ponti. This iconic piece of architecture emerged as a "choral work," with multiple elaborations repre-

senting the different protagonists involved in the design and the path towards its realization: a work of art that developed thanks to the significant contribution of all the protagonists involved in its construction.

Gio Ponti's research on the principles of the "Italianstyle house" - La casa allitaliana ${ }^{67}$ - are integrated with the wishes of the Plancharts, "ideal clients" with precise needs derived from a social and cultural context that the architect was only partially familiar with when he met them for the first time. Villa Planchart represented a challenge that Gio Ponti soon learned to share with decisive figures brought into the project in the execution phase, having recognized the impossibility of managing the site himself. The instrumental role of Mario De Giovanni and Graziano Gasparini emerges clearly from a study of the correspondence, as does equally the contributions of Giordano Chiesa, Romano Rui, and Fausto Melotti, who felt free to bring their own artistic expression into the project: "I think that this work of art will be one of the most important in my life."68 Many choices were influenced by their alternative proposals, which resulted in the modification of important formal and constructive aspects of the building. If one recognizes the built architecture as a sum of layers, we can regard them as having been deeply involved in the creative process, to the same extent as the architect.

Thanks to the detailed study of the archival documents, it is possible to identify those particular influences that are more difficult to detect if the building is regarded as a masterpiece created solely by Gio Ponti. While the ultimate goal was to learn about Villa Planchart's past in order to improve future conservation work, we are now also able to define the multiple origins of those details that make this work of architecture an icon of the modern movement -thus attesting to the inadequacy of narratives that extol individual authorship. RA 
01. GPA Archive, VP, G. Ponti's letter to A. Planchart, March 20, 1956. All the primary and secondary sources in the article were translated into English by the author.

02. IRACE, F., "Corrispondenze: la villa Planchart di Gio Ponti a Caracas," Lotus International, 1988, 60, p. 85.

03. GRECO, A., Gio Ponti: la villa Planchart a Caracas, Edizioni Kappa, Rome, 2008, p. 9.

04. Ibid., p. 9.

05. The research was based on the following archives: Centro Studie Archivio della Comunicazione (CSAC) in Parma; Gio Ponti Archives (GPA) in Milan, Planchart Foundation Archive (AFP) in Caracas.

06. GRECO, A., Gio Ponti: la villa Planchart a Caracas, p. 9.

07. This paper presents part of the results of post-doctoral research carried out by the author in 2020: "Correspondences: Villa Planchart from Design to Materiality," luav University of Venice; academic supervisor: Prof. Sara Di Resta; partners in the research project: Docomomo International ISC $\mathrm{E}+\mathrm{T}$ (arch. Andrea Canziani), Docomomo Venezuela, and the Planchart Foundation. The research is part of the project: "Heritage in Danger: Conservation Between Protection and Emergency in the Case of Villa Planchart," ClusterLab He.Modern, luav University of Venice.

08. "Villa Planchart has to be my masterpiece, a perfect work of art," GPA, VP, G. Ponti's letter to A. Planchart, December 16, 1954.

09. Villa Planchart is also called "El Cerrito." "Cerrito" means "little hill" in Venezuelan Spanish.

10. PONTI, G., "II modello della villa Planchart in costruzione a Caracas," Domus, 1955, 303, p. 11.

11. It was built in 1955 and demolished in 1994 to build a hotel.

12. PORCU, M., and STOCCHI, A., Gio Ponti, tre ville inventate, Abitare Segesta, Milano, 2003.

13. The preliminary drafts for the Pirelli Skyscraper were presented in January
1953. PONTI, G., “Espressione dell'edificio Pirelli in costruzione a Milano," Domus, 1956, 316, pp. 1-16.

14. Both in Domus, 1955, 303, and Domus, 1961, 375.

15. PONTI, G., "Istituto di fisica nucleare a San Paolo," Domus, 1953, 284, pp. 8-11.

16. PONTI, G., "Edificio italiano a Stoccolma," Domus, 1953, 288, 8-11.

17. CANALI, F., "La Fondazione Garzanti a Forli di Gio Ponti," Studi romagnoli, 2006, 57, pp. 775-801.

18. Various images connected with these projects can be found in the GPA Archive website: https://www.gioponti.org/it/ (all URLs here accessed in June 2021)

19. PONTI, G., "Una villa fiorentina," Domus, 1961, 375, p. 2.

20. IRACE, F., "Corrispondenze: la villa Planchart di Gio Ponti a Caracas," Lotus International, 1988, 60, pp. 85-105, esp. p. 85.

21. Ibid

22. FRAILICH-PONTI, L., "Prefacio"; GOMEZ, H., El Cerrito. La obra maestra de Gio Ponti en Caracas, Utreya Ediciones, Caracas, 2009, p. 13.

23. PONTI, G., "Il modello della villa Planchart," p. 10

\section{Domus 303 and Domus 375.}

25. PONTI, G., "Una villa fiorentina," p. 2.

26. FRAILICH-PONTI, L., “Prefacio,” p. 13.

27. "Tell me, what do you like in a house?"- "I like it without walls.." Andres Bello interviews Anala Planchart in the documentary video "El Cerrito," Caracas, 2006.

28. “... He replied that he was not interested for two reasons: first because he had just done a project for Argentina without any result; second, because he preferred building houses to making drafts." IRACE, F., Gio Ponti: la casa all'italiana, Electa, Milan, 1988, p. 153.

29. GPA Archive, VP, A. Planchart's letter to G. Ponti, Lugano, undated.
30. PONTI, G., “Una villa fiorentina,” p. 2.

31. GPA Archive, VP, A. Planchart's letter to G. Ponti, July 14, 1955.

32. Armando Franklin Planchart was born in Caracas in 1906. He opened the city's first General Motors car dealership in the 1940s.

\section{GOMEZ, H., El Cerrito, p. 74.}

34. GRECO, A., Gio Ponti: la villa Planchart a Caracas, p. 9.

35. Hannia Gomez is the actual curator of Planchart Foundation. The interviews with Anala Planchart in 2001 are collected in GOMEZ, H., El Cerrito, cit.

36. GOMEZ, H., El Cerrito, cit., p. 74.

37. The Nouveau Quartier Paraiso was built in 1894. See GOMEZ, H., "La citadela paradiso," EINacional, Caracas, July 20, 2002.

38. GOMEZ, H., El Cerrito, cit., p. 88.

39. Ibid., p. 77.

40. Ibid.

41. GPA Archive, VP, A. Planchart's letter to G. Ponti, Especificaciones aproximadas de la casa, Caracas, undated.

42. Vera H., 1951. Edificio CARS, Fundaciòn Arquitectura y Ciudad, July 13, 2018. (https://fundaayc.wordpress.com/tag/ pedro-agustin-dupouy)

43. GRECO, A., Gio Ponti: la villa Planchart a Caracas, p. 13

44. Ibid., p. 9.

45. GPA Archive, VP, G. Ponti's letter to A Planchart, October 1, 1955

46. "Mr. Planchart had the really good idea to waterproof the patio walls," GPA Archive, VP, G. Ponti's letter to M. De Giovanni, June 27, 1956.

47. GPA Archive, VP, G. Ponti's letter to A Planchart, November 23, 1955.

48. Armando and Anala Planchart organized an extended trip to Asia and Africa at the beginning of 1955. GPA Archive, VP, 
A. Planchart's letter to G. Ponti, December 21, 1954.

49. GPA Archive, VP, G. Ponti's letter to A. Planchart, March 15, 1954.

50. In the correspondence, Mario De Giovanni is referred to as both "engineer" and "architect."

\section{GOMEZ, H., El Cerrito, cit., p. 138.}

52. GPA Archive, VP, G. Ponti's letter to M. De Giovanni, February 8, 1955.

53. GPA Archive, VP, G. Ponti's letter to M. De Giovanni, November 2, 1956.

54. GPA Archive, VP, M. C. Ferrario's letter to M. De Giovanni, August 4, 1955.

55. "I have to modify structures," GPA Archive, VP, M. De Giovanni's letter to G. Ponti, June 23, 1955.

56. GPA Archive, VP, M. De Giovanni's letter to G. Ponti, January 28, 1955.

57. GPA Archive, VP, G. Ponti's letter to M. De Giovanni, March 9, 1955.

58. GPA Archive, VP, M. De Giovanni's letter to G. Ponti, March 21, 1954.

59. GPA Archive, VP, M. C. Ferrario's letter to M. De Giovanni, April 15, 1955.

60. GPA Archive, VP, G. Ponti's letter to A. Planchart, September 7, 1956.

61. GPA Archive, VP, M. De Giovanni's letter to G. Ponti, May 4, 1956.

62. GPA Archive, VP, G. Ponti's letter to M. De Giovanni, September 6, 1956.

63. PONTI, G., "Graziano Gasparini,," Domus, 1954, 294; PONTI, G., "Tre costruzioni: Graziano architetto in Venezuela," Domus, 1954, 299; PONTI, G., "In Venezuela: casa al mare a Macuto, Casa a tre piani a Caracas," Domus, 1959, 377; GASPARINI, G., "A Caracas una casa piena di quadri," Domus, 1956, 323; GASPARINI, G., "Casa e piscina," Domus, 1957, 327.

64. GPA Archive, VP, G. Gasparini's letter to G. Ponti, July 18, 1957.
65. GPA Archive, VP, G. Ponti's letter to A. Planchart, August 24, 1956.

66. GPA Archive, VP, G. Ponti's letter to A. Planchart, February 22, 1954.

67. PONTI G, "La casa all'italiana," Domus, 1928, 1, p. 7; IRACE, F, Gio Ponti, la casa all'italiana, Electa, Milano, 1988; PONTI, G, Amate l'architettura, Rizzoli, Milano, edizione 2018.

68. GPA Archive, VP, F. Melotti's letter to A. Planchart, June 9, 1956. 


\section{Bibliography}

- CANALI, F., "La Fondazione Garzanti a Forli di Gio Ponti,” Studi romagnoli, 2006, 57, pp. 775-801.

- GASPARINI, G., "A Caracas una casa piena di quadri," Domus, 1956, 323, pp. 4-10.

- GASPARINI, G., "Casa e piscina," Domus, 1957, 327, pp. 12-14.

- GOMEZ, H., "La citadela paradiso," El Nacional, Caracas, July 20, 2002.

- GOMEZ, H., El Cerrito. La obra maestra de Gio Ponti en Caracas, Utreya Ediciones, Caracas, 2009.

- GRECO, A., Gio Ponti: la villa Planchart a Caracas, Edizioni Kappa, Roma, 2008.

-IRACE, F., "Corrispondenze: la villa Planchart di Gio Ponti a Caracas," Lotus International, 1988, 60, pp. 85-105.

- IRACE, F., Gio Ponti: la casa allitaliana, Electa, Milano, 1988.

- NECCHI, S., Gio Ponti. La Villa Planchart, un progetto per corrispondenza (1953-1957), PhD dissertation, Universidad Politécnica de Catalunya, Departemento de Proyectos Arquitectònicos, Barcelona, 2012.

- PONTI, G., "La casa all'italiana," Domus, 1928,1, p. 7.

- PONTI, G., "Istituto di fisica nucleare a San Paolo," Domus, 1953, 284, pp. 8-11.

- PONTI, G., "Edificio italiano a Stoccolma," Domus, 1953, 288, pp. 8-11.

- PONTI, G., "Graziano Gasparini," Domus, 1954,294, p. 41.

- PONTI, G., "Tre costruzioni: Graziano architetto in Venezuela," Domus, 1954, 299, pp. 20-21.

- PONTI, G., "Il modello della villa Planchart in costruzione a Caracas," Domus, 1955, 303, pp. 8-14.

- PONTI, G., "Espressione dell'edificio Pirelli in costruzione a Milano," Domus, 1956, 316, pp. 1-16.

- PONTI, G., "Una villa fiorentina," Domus, 1961, 375, pp. 1-39.
- PONTI, G., "In Venezuela: casa al mare a Macuto, Casa a tre piani a Caracas," Domus, 1959, 377, pp. 22-23.

- PONTI, G, Amate l'architettura, Rizzoli, Milano, 2018 edition.

- PORCU, M., and STOCCHI, A., Gio Ponti, tre ville inventate, Abitare Segesta, Milano, 2003.

- VERA, H., "1951. Edificio CARS," Fundaciòn Arquitectura y Ciudad, July 13, 2018; https://fundaayc.wordpress.com/tag/ pedro-agustin-dupouy
RA. Revista de Arquitectura Núm. 23 - 2021 P. 116-131 